\title{
Participation of Students with Hearing Impairment in Inclusive Classes
}

\author{
Siti Musayaroh, Imas Diana Aprilia \\ Universitas Pendidikan Indonesia, Indonesia \\ E-mail: sitimusayaroh@student.upi.edu
}

\begin{abstract}
One indicator of the success of the learning process is the active role of all students. The aim of this study was to find out how the participation of students with hearing impairment during learning process in inclusive classes. This research use descriptive method. Three students with hearing impairment have been selected according to predefined criteria. The data was collected by observation, interview and documentation. The data were analyzed through data reduction, data display and conclusion or verification. The results show that participation of students with hearing impairment during the learning process in inclusive classes is not very active. The way teachers teach, the lack of their understanding on learning materials and the presence of other special needs students in same classes influences their active participation during the learning process in the inclusive classes.
\end{abstract}

Keywords: sarticipation, students with hearing impairment, hearing impairment, inclusive classes

One indicator of successful learning in inclusive classes is the active participation of all students in the class (Antia, Sabers \& Stinson, 2007; Antia, Jones, Reed and Kreimeyer: 2009), including students with hearing impairment. According to Stinson and Antia (1999), one of the main components of academic success is the ability of students with hearing impairment to communicate with teachers and peers. Communication between teachers and students or communication between students and students is the main learning tool in the classroom. Student activeness in class participation depends on communication skills and the atmosphere of the class (Kawabe, Yamamoto, Aoyagi and Watanabe, 2014).

But the problem is the hearing impairment experienced by the students with hearing impairment affects the activity of the learning process (Iglesias, Jiménez, Revuelta \& Moreno, 2014) because one of the impacts of hearing impairment experienced by them is the obstacle in communication. Although most students with hearing impairment have no intellectual barriers but still communication barriers will hamper their learning in inclusive classes. This leads to significant differences in ability between students with hearing impairment and regular students in inclusive classes.

Some studies indicate that students with hearing impairment in inclusive classes have difficulty following and understanding the learning materials. Although their social interaction is good, but the participation of students in inclusive classes is not as good as their social interactions beyond the classroom (Rekkedal, 2016).
Research on the participation of students with hearing impairment in the same class as regular students has been done by Stinson and Liu (1999). What distinguishes this research from previous research lies in the subject of the study. Subjects in Stinson and Liu's research are 40 staff members who provide support to students with hearing impairment in primary and secondary classes in regular classes such as special teachers and interpreters, along with a few paid notetakers. While in this study, the subject of research is students with hearing impairment and some subject teachers who have hours of teaching 2-3 meetings a week in inclusive classes.

\section{METHOD}

The method used in this research is descriptive method. The study was conducted in a junior high school which has been accredited A in the city of Bandung. Selection of the school because the school has held inclusive education for more than ten years, by receiving students with special needs, including students with hearing impairment to study together with regular students.

Table 1 describes the research subjects selected in this study. Three students with hearing impairment were chosen by purposeful sampling technique. The criteria of students with hearing impairment are: 1) students with hearing impairment who have no additional barriers, such as visual impairment, intelectual disability, etc 2) students with hearing impairment studying in inclusive classes in full, and 3) students with hearing impairment aged between $12-15$ years. 
Table 1. Research Subjects

\begin{tabular}{cccc}
\hline No. & Subject & Gender & Class \\
\hline 1 & A & Male & 3 Junior high school \\
2 & B & Female & 1 Junior high school \\
3 & C & Female & 1 Junior high school \\
\hline
\end{tabular}

Table 2. Active Participation of Students with Hearing Impairment during the Learning Process in Inclusive Classes

\begin{tabular}{|c|c|c|c|}
\hline Aspect & Subject A & Subject B & Subject C \\
\hline \multicolumn{4}{|l|}{$\begin{array}{l}\text { Respond- } \\
\text { ing }\end{array}$} \\
\hline $\begin{array}{l}\text { to a ques- } \\
\text { tion and }\end{array}$ & $\mathrm{X}$ & $\mathrm{X}$ & $\mathrm{X}$ \\
\hline \multicolumn{4}{|l|}{ answer } \\
\hline Asking & $\begin{array}{l}\sqrt{ } \\
\text { (only with } \\
\text { a swing } \\
\text { classmate } \\
\text { at the } \\
\text { m o m e } n t \\
\text { peer tutor- } \\
\text { ing) }\end{array}$ & $\begin{array}{l}\sqrt{ } \\
\text { (ask the } \\
\text { teacher face } \\
\text { to face and } \\
\text { peer at the } \\
\text { time peer tu- } \\
\text { toring) }\end{array}$ & $\begin{array}{l}\sqrt{ } \\
\text { (ask the } \\
\text { teacher face } \\
\text { to face and } \\
\text { peer at the } \\
\text { time peer tu- } \\
\text { toring). }\end{array}$ \\
\hline Arguing & X & $\mathrm{X}$ & $\mathrm{X}$ \\
\hline Discussion & $\mathrm{X}$ & $\mathrm{X}$ & $\mathrm{X}$ \\
\hline \multicolumn{4}{|l|}{ Description : } \\
\hline $\begin{array}{l}X=\text { Can not } \\
\sqrt{ }=\text { Can do }\end{array}$ & do & & \\
\hline
\end{tabular}

\section{FINDING AND DISCUSSION}

\section{Findings}

The results showed that the communication between students with hearing impairment with the teacher during the learning process in inclusive classes is one-way communication. Where students with hearing impairment only acts as the recipient of information from the teacher without any back response. Therefore, the role of teachers is to become a source of information for students with hearing impairment in all learning activities. This is different from regular students. The ability of regular students in responding to questions and answers, asking and issuing opinions to make communication in the learning process runs in both directions is the existence of mutual communication between teachers and regular students and even walk in many directions that not only occur between students and teachers but also between students and students.

Student participation during the learning process can be seen from behaviors during their involvement in group discussions, responding to teacher questions, and providing feedback.
Table 2 shows that responding to teacher questions, opinions and discussions are aspects that students with hearing impairment are difficult to follow. The three subjects of students with hearing impairment show the same thing that they tend to be passive by just sitting still folded hands on the table while watching the teacher. However, they still find it difficult to understand what the teacher is saying.

The inability of students with hearing impairment responds to questions and answers given by the teacher during the learning process because they are less able to capture and understand the information provided by the teacher. The way teachers teach students in inclusive classes is the same as the way they teach students in a class where there are no students with special needs. In addition, the absence of special teachers in the classroom to help transfer information from teachers to students with hearing impairment makes them take longer than regular students to understand all information.

Regular students' willingness to help students with hearing impairment when experiencing difficulty in classroom learning makes students with hearing impairment more comfortable in asking regular students than asking their teachers. Potential is supported by the teacher by asking a friend of the students with hearing impairment to become peer tutors for students with hearing impairment. The role of these peer tutors is to help students with hearing impairment when they are not familiar with teacher instructions and explanations and borrow notes when teachers do dictation.

During this time, Subjects B and C learn in one classroom. In addition, in their class there is also a student with special needs namely intelectual disability. Interestingly, the existence of the subject B and C in one of the same classrooms makes him more confident in learning than the only subject A who experiences special needs in the classroom where he studies. It is seen when asking questions about the less obvious material. Although the three subjects were able and willing to ask for help to peers when having trouble in the classroom, only subjects B and C dared to ask the teacher even though the face to face was not in the middle when the teacher explained.

\section{Discussion}

The participation of students with hearing impairment tends to be lower than regular student participation during the learning process. This is due to the hearing impairment they have. Hearing impairment are known to cause a variety of psychosocial, mental and physical effects that lead to widespread limitations of activity and restrictions on participation between children with hearing impairment and hearing children (Manchaiah and Stephens, 2011). Powell, Hyde and Punch (2014) said that the most students with hearing impairment, their learning experience and academic 
participation are severely hampered by communication barriers.

Passive attitude of students with hearing impairment in inclusive classes seen from less able to respond to questioning, opinion and involve themselves actively in discussion activities. The students need more time to understand information than the regular students need, so they are difficult to respond to questions and answers. According to Stinson and Liu (1999), it takes additional time for students to understand the questions asked by their teachers or colleagues and to answer them correctly. Group communication and interaction skills take time.

Kyle (2006) argues that students with hearing impairment have difficulty in following class discussions. Students with hearing impairment need information to attend group discussions and need to know when to participate so to support their participation in group discussions need to: 1) fill in "gaps" when students with hearing impairment have no specific information on the topic being discussed, 2) adapt to certain situational requirements, and 3) assist members of the education team with planning activities where students with hearing impairment can participate (Stinson \& Liu, 1999).

The way teachers teach in the classroom affects students' understanding of receiving information about the material presented by the teacher. According to Charema (2010), the importance of regular school teachers in the process of inclusion can not be underestimated because the success of students with hearing impairment depends on their attitude and willingness to accommodate and attend to the needs of students with hearing impairment. In following the learning process, students with hearing impairment is very much dependent on what is said by the teacher (Smith, 2012). According to Holmström and Schönström (2017), the opportunity of student participation with hearing impairment in inclusive classes depends on the efforts of each teacher teaching in the class.

Interpreters' and special teacher's inclusive classroom experiences help students with hearing impairment in inclusive classes in understanding the material presented by teachers and bridging them in interactive communication. Unfortunately, not all inclusive schools have special teachers or interpreters. Under these circumstances, where there are no interpreters in inclusive classes, general teachers are often unaware of the degree of communication difficulties students experience, especially in listening conditions (Punch \& Hyde, 2010). Therefore the absence of interpreters in inclusive classes makes the main barriers that affect the participation of students with hearing impairment in the listening community, including the quality of education and socializing (Murray, Klinger, and McKinnon, 2007).
Peer tutors really help students with hearing impairment in overcoming difficulties during the learning process. Foster, Long and Snel (1999) argue that the availability of tutors contributes to students with hearing impairment who have less ability than the regular students have to try and solve learning problems independently.

The presence of special needs with fellow friends provide a sense of comfort that increases student confidence. This is because they feel there is a friend of the same fate experiencing the same thing with what they feel. According to Nakken and Pijl (2002) students with hearing impairment tend to prefer to be friends with other students with hearing impairment in inclusion schools because of their limitations in communicating.

\section{CONCLUSSION AND SUGGESTION}

\section{Conclusion}

The participation of students with hearing impairment in inclusive classes tends to be passive when compared to regular student participation. Lack of active students with hearing impairment during the learning process is less able to respond to teacher questions, to give opinion and actively involved in a discussion. The way teachers teach, the lack of understanding of students with hearing impairment on learning materials and the presence of fellow hearing impaired or other special needs students in the same inclusive classes influences their active participation during the learning process in the inclusive classes.

\section{Suggestion}

To enforce the participation of students' participation in the learning process, it is needed the peer tutors really help the students to overcome their learning difficulties. Also, the role of accompanying teachers is needed to assist them in the learning process.

\section{REFERENCES}

Antia, S. D., Sabers, D. L., \& Stinson, M. S. (2007). Validity and Reliability of the Classroom Participation Questionnaire With Deaf and Hard of Hearing Students in Public Schools. Journal of Deaf Studies and Deaf Education, 12(2), 154-171. Retrieved from https://academic.oup.com/jdsde/ article/12/2/158/451581

Charema, J. (2010) Inclusion of Primary School Children With Hearing Impairments in Zimbabwe. Africa Education Review, 7(1), 85 - 106. Retrieved from http:/www.tandfonline.com/doi/ abs/10.1080/18146627.2010.48581 0 
Foster, S., Long, G., and Snel, K. (1999). Inclusive Instruction and Learning for Deaf Students in Postsecondary Education. Journal of Deaf Studies and Deaf Education, 4(3), 225-235. Retrieved from https://academic.oup.com/jdsde/ article/4/3/225/440898

Holmström, I. and Schönström, K. (2017). Resources for Deaf and Hard-Of-Hearing Students in Mainstream Schools in Sweden. A survey. Deafness \& Education International, 19(1), 1-11. Retrieved from http://www.tandfonline.com/doi/ abs/10.1080/14643154.2017.1292670

Iglesias, A., Jiménez, J., Revuelta, P., \& Moreno, L. (2014). Avoiding communication barriers in the classroom: the APEINTA project. Journal of Interactive Learning Environments, 24(4), 829843. Retrieved from http://dx.doi.org/10 .1080/10494820.2014.924533

Kawabe, R., Yamamoto, M., Aoyagi, S., \& Watanabe, T. (2014). Measurment of Hand Raising Actions to Support Student' Active Participation in Class. Human Interface and the Management of Information. 8521, 199-207. Retrieved from https://link.springer.com/chapter/10.1007/978 -3-319-07731-4_20

Kyle, J. G. (2006). Integration of deaf children. European Journal of Special Needs Education, 8(3). 201220. Retrieved from http://www.tandfonline.com/ doi/abs/10.1080/0885625930080303

Nakken, H. \& Pijl, S. J. (2002). Getting Along With Classmates In Regular Schools : A Review Of The Effects Of Integration On The Development Of Social Relationships. International Journal of Inclusive Education, 6(1), 47-61. Retrieved from http://www.tandfonline.com/doi/ abs/10.1080/13603110110051386
Manchaiah, V. K. C., \& Stephens, D. (2011). Models To Represent Communication Partners Within The Social Networks Of People With Hearing Impairment. Audiological Medicin,. 9(3), 103109. Retrieved from http://www.tandfonline.com/ doi/abs/10.3109/00365521.2011.59922 8

Murray, J. B., Klinger, L., and McKinnon, C. C. (2007). The Deaf: An Exploration of Their Participation in Community Life Jillian. SAGE Journals, 27(3). 113-120. Retrieved from http://journals.sagepub. com/doi/abs/10.1177/153944920702700305

Powell, D., Hyde, M., \& Punch, R. (2014). Inclusion in Postsecondary Institutions With Small Numbers of Deaf and Hard-of-Hearing Students: Highlights and Challenges. Journal of Deaf Studies and Deaf Education, 19(1), 126-140. Available: https:// academic.oup.com/jdsde/article/19/1/126/393408.

Rekkedal, A. M. (2016). Factors Associated with School Participation Among Students with Hearing Loss. Scandinavian Journal of Disability Research, 19(3), 1-19. Retrieved from https://doi.org/10.10 80/15017419.2016.1167771

Smith, J. D. (2012). Sekolah Inklusif: Konsep dan Penerapan Pembelajaran. (Denis, Ny. Enrica, Trans). Bandung: Nuansa Cendekia. (Original work published 1998).

Stinson, M. S., \& Liu, Y. (1999). Participation of Deaf and Hard-of-Hearing Students in Classes with Hearing Students. Journal of Deaf Studies and Deaf Education, 4(3), 192-202. Retrieved from https:// academic.oup.com/jdsde/article/4/3/191/440895

Stinson S. M., \& Antia, S. D. (1999). Considerations in Educating Deaf and Hard-of-Hearing Students in Inclusive Settings. Journal of Deaf Studies and Deaf Education, 4(3), 163-175. Retrieved from https://academic.oup.com/jdsde/ article/4/3/163/440893 